\title{
Terapia neoadyuvante en cáncer de mama
}

\author{
Neoadyuvant therapy for breast cancer
}

Pedro Ramos ${ }^{1}$

'Clínica Oncocare.

$\mathrm{L}$ a terapia neoadyuvante en cáncer de mama se refiere al tratamiento sistémico previo a cirugía (preoperatorio), que tradicionalmente está indicada en cáncer de mama localmente avanzado independiente del estado de receptores y HER2, para permitir cirugía cuando es irresecable y, cuando es resecable, realizar cirugía conservadora, además de evaluar la efectividad de la terapia sistémica por medio de la respuestas patológicas completas (PCR) y los marcadores de respuesta y resistencia en especímenes de sangre y tejidos.

El uso de terapia neoadyuvante en la enfermedad inicial estadios I y II está indicada si la relación mamatumor no permite cirugía conservadora para mejorar los resultados estéticos y disminuir complicaciones, como el linfoedema; en los pacientes triple negativos y HER2, se utiliza aun en tumores pequeños, porque se asocian a altas respuestas patológicas y mejoría en desenlaces a largo plazo; en receptores positivos, se puede emplear si se quiere cirugía conservadora y la relación tumor-mama no lo permite.

En pacientes con compromiso axilar N1, se usa para obviar la disección axilar y efectuar ganglio centinela, que reduce las complicaciones, como el linfoedema, y en casos en que se requiera diferir la cirugía, como en las mujeres embarazadas o por otras razones médicas.

Desde el estudio NSABP 18, sabemos que la administración de la quimioterapia neoadyuvante versus la adyuvante se asocia con los mismos resultados en supervivencia libre de enfermedad y global.

Se define respuesta patológica completa como la ausencia de enfermedad invasiva residual en la mama y axila (ypt0/is, ypn0); la enfermedad residual in situ no afecta el riesgo de recurrencia a distancia.
La evaluación previa al tratamiento quirúrgico se hace con eco y mamografía; en casos seleccionados, se emplea la resonancia magnética, pero esta no afecta los resultados finales y aumenta la realización de mastectomías; es útil en mamas densas, multicentricidad, compromiso profundo axilar, de la mamaria interna y pared torácica, pero hay que balancear riesgos de falsos positivos.

Los estudios de extensión en estadios I y II están indicados solo por síntomas y anormalidades de laboratorios, en estadio III sí son rutinarios.

Evaluación ganglionar axilar: si hay ganglios palpables, Bacaf o trucut; y si no son palpables, ultrasonido; si son sospechosos, biopsia; si hay ganglios positivos, se marcan con clic para disminuir falsos negativos del $1,4 \%$ versus el $10,1 \%$ con ganglio centinela; si los ganglios son negativos, se sugiere centinela inicial o centinela después de la neoadyuvancia.

Respecto al tipo de terapia neoadyuvante, se usa la quimioterapia, terapias blanco y, en algunos casos, la hormonoterapia; se han utilizado antiangiogénicos sin buenos resultados y se investiga el empleo de los inhibidores PARP, inhibidores de ciclinas, everolimus y fulvestrant.

En los pacientes triple negativos, el esquema más usado es antraciclinas más taxanos, idealmente dosis densas; se adiciona en casos de alto riesgo carboplatino, que incrementa las PCR, pero no es clara la mejoría en los resultados a largo plazo; hay estudios iniciales con inhibidores PARP en curso; en casos de contraindicación de antracíclicos, se pueden utilizar platinos con taxanos.

En los pacientes que son HER2 positivos, la neoadyuvancia incluye el uso de trastuzumab más 
quimioterapia, que aumenta la PCR, la supervivencia libre de eventos y la global; además, el empleo de pertuzumab en paciente de alto riesgo incrementa la PCR, está pendiente demostrar resultados a largo plazo. El uso con lapatinib en combinación aumenta también la PCR sin demostrar resultados a largo plazo.

En pacientes con receptor hormonal positivo, si es localmente avanzado, deben recibir terapia neoadyuvante; y si es estadio II, puede hacerse cirugía inicial o neoadyuvancia; si desea cirugía conservadora y hay mala relación tamaño tumoral-tamaño de la mama, en premenopáusicas se usa quimioterapia preferiblemente, dado que los resultados con hormonoterapia son inferiores; en posmenopáusicas, los resultados son similares, pero se prefiere quimioterapia y se reserva para pacientes con comorbilidad, frágiles o que no desean quimioterapia. En los esquemas se prefiere inhibidores de aromatasa sobre tamoxifen; las nuevas opciones combinadas con inhibidores de ciclinas, everolimus, fulvestrant están en investigación.

En el estudio de Ramos y colaboradores, publicado en este número, se analiza la neoadyuvancia con quimioterapia en el grupo de pacientes HER2 positivo, triple negativos y receptores positivos, con información de PCR y de resultados a largo plazo; las PCR para HER2 fueron del $27 \%$ y los tiempos de sobrevida libre de enfermedad se ven disminuidos por el compromiso de 10 o más ganglios HR 2,96 (IC95\% 1,24-3,27) y se aumentan en respuestas patológicas completas HR 0,29 (IC95\% 0,11-0,72).

Los tiempos de sobrevida global se ven reducidos por el compromiso de 10 o más ganglios HR 2,93 (IC95\% 1,29-6,66) y se incrementan en respuestas patológicas completas HR 0,43 (IC95\% 0,21-0,87); durante el seguimiento se observaron $81(23,14 \%)$ eventos de recaída y 70 (20\%) eventos de muerte.

Estos resultados de disminución en la supervivencia en asociación con compromiso ganglionar masivo de 10 o más ganglios, lo mismo que la asociación de PCR con mejorías en la supervivencia, concuerdan con los publicados en la literatura.

En conclusión, este estudio permite tener información en nuestro país de nuestra práctica clínica, de interés y motivación para generar más investigación en este tema en los diferentes grupos de oncología. 